Research Article

\title{
Thermal Performance Test of a Phase-Change-Material Cool Roof System by a Scaled Model
}

\author{
Suk Goo Yoon, Young Kwon Yang, Tae Won Kim, Min Hee Chung, and Jin Chul Park \\ School of Architecture and Building Science, Chung-Ang University, Seoul, Republic of Korea \\ Correspondence should be addressed to Jin Chul Park; jincpark@cau.ac.kr
}

Received 7 December 2017; Accepted 5 February 2018; Published 1 April 2018

Academic Editor: Geun Y. Yun

Copyright (C) 2018 Suk Goo Yoon et al. This is an open access article distributed under the Creative Commons Attribution License, which permits unrestricted use, distribution, and reproduction in any medium, provided the original work is properly cited.

General cool roof is effective for reduction of cooling load, but it has a problem of increasing heating load. Therefore, the purpose of this study is to complement the disadvantages of the cool roof system by utilizing phase change characteristics of phase change material (PCM). The study was carried out to verify the thermal performance of the PCM cool roof system by measuring the temperature on the top and bottom of the PCM cool roof system by making a miniature model $(600 \times 600 \times 600 \mathrm{~mm})$. PCM was inserted and not inserted, and the temperature difference according to the finish color (brown and white) was compared. As a result, the plate surface temperature using PCM was lower than that without PCM, and time-lag of temperature increase occurred. As a result of the comparison of temperature according to the finish color (brown and white), white showed a low temperature distribution up to $16.35^{\circ} \mathrm{C}$. Even at room temperature, white maintained a low temperature distribution of $5.40^{\circ} \mathrm{C}$ than brown. The use of PCM cool roof system in roof finishes could lower the surface temperature and keep the room temperature low.

\section{Introduction}

A cool roof can increase the reflectivity and emissivity of a roof's surface, which results in a lower surface temperature compared to general roof finishes. Cool roofs are effective at cooling in the summer because they minimize the solar heat gain on the roof. However, they increase the heating load in winter [1]. Various studies have been conducted to overcome this drawback. One solution is to apply phase-change materials (PCMs) to cool roofs [2-9].

A PCM can change phase from solid to liquid or liquid to solid at different temperatures. This characteristic can be used to store and emit heat energy as a form of latent heat [10]. A phase-change cool roof can prevent over-heating of the roof surface during summer and without increasing the heating load in winter. The decreased variation in the indoor temperature can make occupants feel more comfortable throughout the year. This study demonstrates the improvements in energy savings and comfort using a PCM cool roof system.

\section{Literature Review}

The roof of a building accounts for approximately $14 \%$ of the total cooling load in a general residential house, which means that a large amount of energy could be saved through the roof [11]. Chou et al. [12] evaluated the thermal performance of a general roof, an insulated roof, and an insulated PCM roof. They measured the surface temperatures at the upper and lower sides of the roof and the indoor temperature. The insulated PCM roof exhibited the lowest temperature, whereas the general roof without insulation resulted in a higher indoor temperature.

Karlessi et al. [13] conducted a study on reducing the surface temperature by coating tiles with paint containing a PCM. The surface temperatures of the tiles with six different colors were analyzed, and the surface temperatures were reduced by $3-7^{\circ} \mathrm{C}$ when the PCM was applied, depending on the color. Pasupathy and Velraj [14] installed PCM panels on the roof of a testing room with dimensions of $1.22 \times 1.22 \times 2.44 \mathrm{~m}^{3}$ and measured the change in temperature at the ceiling surface. When PCM panels were not inserted, the indoor temperature 


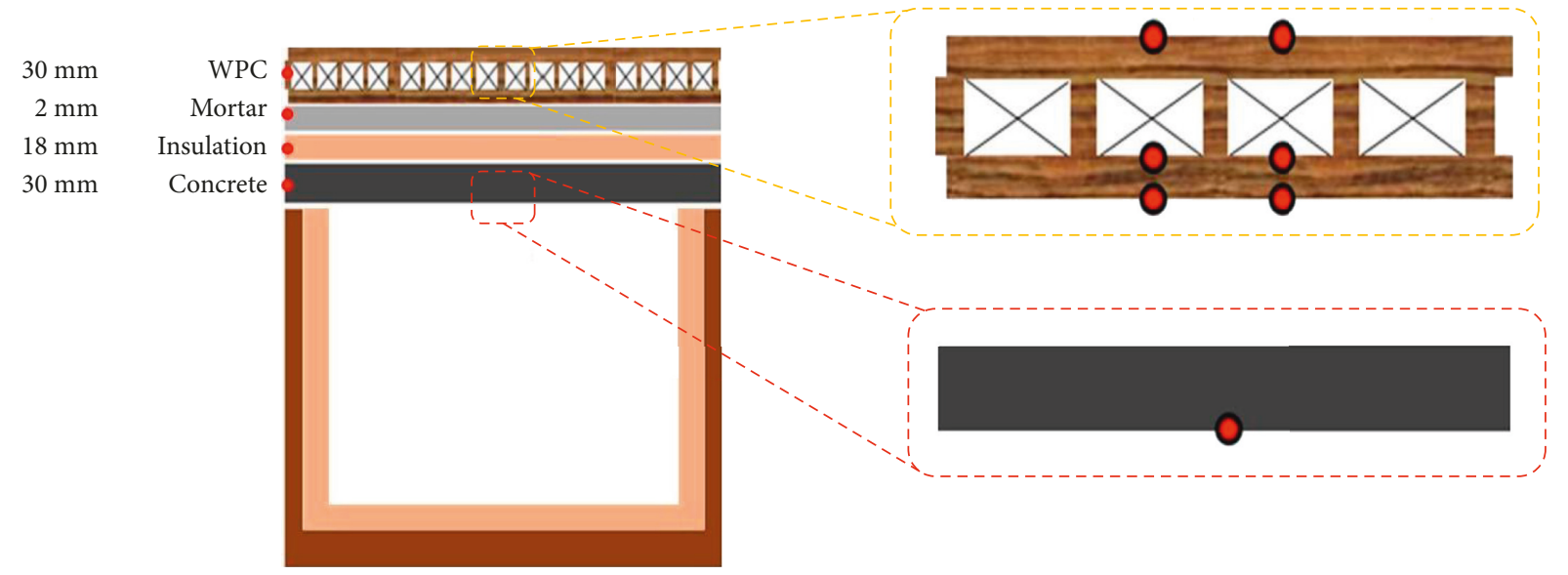

FIgURE 1: Scale-model cross section and temperature sensor locations.

of the ceiling surface was in the range of $23-30^{\circ} \mathrm{C}$. However, the range was $27-28^{\circ} \mathrm{C}$ when the PCM panels were inserted, indicating a relatively constant temperature distribution.

Other studies on the application of PCMs to roof surfaces have also been conducted to reduce the occurrence of urban heat islands (UHIs). Roman et al. [15] combined roof finishes such as metal or concrete with PCMs to reduce the effect of UHIs. Lu et al. [16] inserted a PCM into a PE-RT pipe to analyze the UHI reduction and the change in building energy efficiency in Tianjin, China. Chung [17] studied the reduction in surface temperature that resulted from applying according PCM tile, cool paint, green waterproof finish, and gray waterproof finish to a scale model. PCMs were sprayed over general tiles. Phase Change Energy Solutions in the USA applied "BioPCMatTM" [18] to the roofs of residential buildings. They reported total energy savings of approximately 30\% during summer when BioPCMatTM was installed with a cool roof in a hollow layer. These studies show that the temperature variation is stabilized when PCMs are applied to roof finishes. In particular, adding cool roof materials was more effective for reducing the thermal load.

\section{Methodology}

To test the performance of a PCM cool roof, a scale model, WPC, and packing-type PCMs were fabricated. The WPC was found to be appropriate for the PCM cool roof system based on comparison tests with general wood in previous studies [10]. A PCM cool roof system was fabricated, followed by a scale-model test. The study method and scope for each phase are as follows:

Phase 1: fabrication of packing-type PCM

Phase 2: fabrication of the PCM cool roof system by inserting packing-type PCM into a wood plastic composite (WPC)

Phase 3: applying the fabricated PCM cool roof system to a scale model

Phase 4: performance test using different roof surface colors (white and brown) in the scale model
TABLE 1: WPC thermal conductivity measurement results including the hollow layer.

\begin{tabular}{lcc}
\hline $\begin{array}{l}\text { Measurement } \\
\text { interval }\end{array}$ & $\begin{array}{c}\text { Effusivity } \\
\left(\mathrm{Ws}^{1 / 2} / \mathrm{m} \cdot \mathrm{K}\right)\end{array}$ & $\begin{array}{c}\text { Thermal conductance } \\
(\mathrm{W} / \mathrm{m} \cdot \mathrm{K})\end{array}$ \\
\hline 1 & 887.9944 & 0.529941 \\
2 & 888.5313 & 0.530477 \\
3 & 889.8055 & 0.53175 \\
4 & 894.8415 & 0.536787 \\
5 & 890.3037 & 0.532248 \\
6 & 889.1223 & 0.531067 \\
7 & 893.0003 & 0.534945 \\
8 & 891.1271 & 0.533071 \\
9 & 894.2066 & 0.536152 \\
10 & 888.4203 & 0.530366 \\
& Average & 0.53268 \\
\hline
\end{tabular}

3.1. Fabrication of Scale Models. The scale models of a roof cross section from a small general office building were fabricated with a scale of $1 / 10\left(600 \times 600 \times 600 \mathrm{~mm}^{3}\right)$. To prevent heat exchange through the walls and floors, $40 \mathrm{~mm}$ of insulation was used in the finish. The basic structure of the roof was made from deck plate, mortar, insulation, and concrete, as shown in Figure 1. This structure was referenced from general roof structures used in South Korea. Temperature sensors were installed on the upper and lower sides of the plate and on the lower side of the concrete at the indoor side. The sensors were used to measure the heat transfer from the roof surface to each of the structural layers.

3.2. Fabrication of WPC and Packing-Type PCM. The WPC was first utilized to apply the PCM to the roof layer. The WPC consisted of a lower bottom plate, an internal hollow layer containing PCM, and an upper surface cover used as an exterior material. The plate was designed to have modular size for application in various areas. The thermal conductivity of the WPC plate was measured using a thermal conductivity analyzer (TCi), which measures the degree to which a given amount of heat is supplied to the object and its thermal energy raises the temperature. The mean value calculated from 10 measurements with the hollow layer included was $0.53 \mathrm{~W} / \mathrm{m} \cdot \mathrm{K}$ (Table 1$)$. 


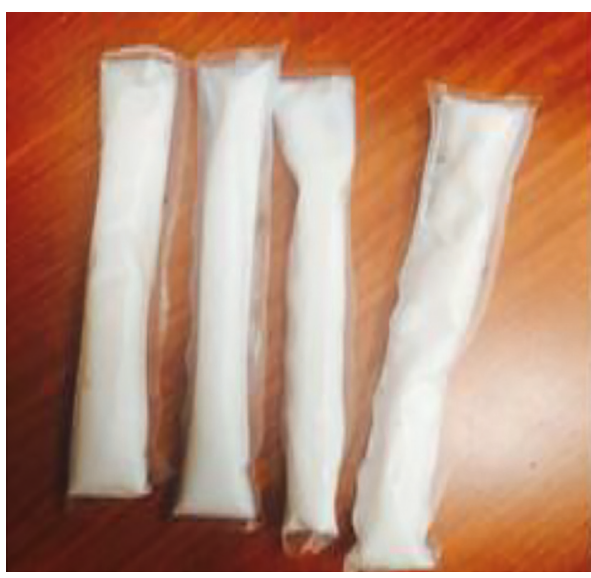

(a)

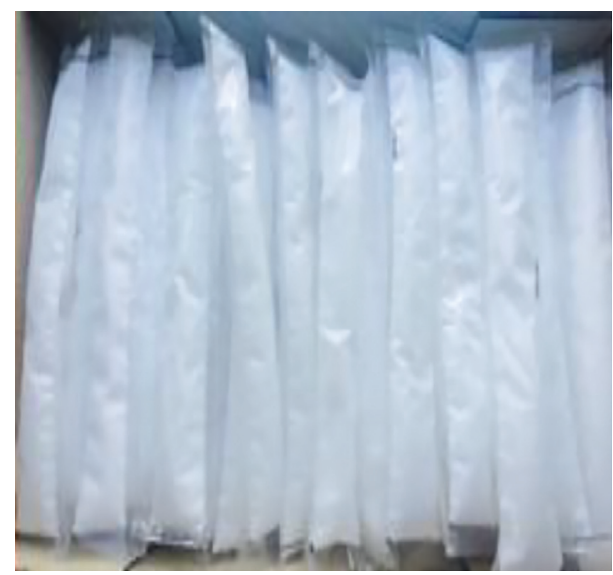

(b)

FIgure 2: Packing-type PCM: (a) Bio $26^{\circ} \mathrm{CPCM}$, (b) RT $44^{\circ} \mathrm{C}$ PCM.

Table 2: Summary of Test 1 (Bio $26^{\circ} \mathrm{C}$ PCM, RT $44^{\circ} \mathrm{C}$ PCM).

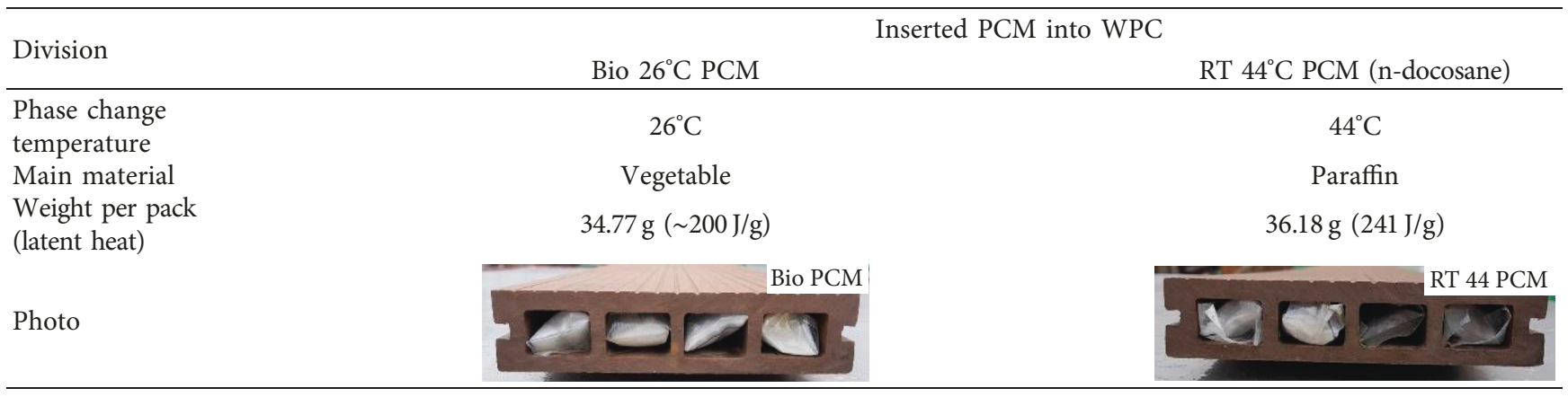

Since the PCM can be liquid or solid at different temperatures, a container is needed to store it. A packing-type PCM was fabricated and injected into a transparent pack made of nylon to maximize the thermal storage performance without causing damage due to PCM leakage. Each pack was $15 \times 3 \mathrm{~cm}^{2}$, and the weight of the injected PCM was $35 \pm 1 \mathrm{~g}$ (Figure 2).

\section{Scale-Model Test}

4.1. Test according to PCM Melting Point $\left(26^{\circ} \mathrm{C} / 44^{\circ} \mathrm{C}\right)$ (Test 1). In Test 1 , the WPC was installed on the upper surface of the scale model. Two different PCMs with different phasechange temperatures were tested: BioPCM of Bio series (melting point: $26^{\circ} \mathrm{C}$ ) and n-Paraffin series RT-PCM of $\mathrm{R}^{\circledR}$ (melting point: $44^{\circ} \mathrm{C}$ ). A comparative test was then conducted using a WPC plate without the PCM (Table 2).

The test was conducted at the rooftop of the building in Chung-Ang University located in Heukseok-dong, Dongjakgu, Seoul, from September 22 to 24, 2015. The weather conditions had no interference from solar radiation. The mean cloud cover was 4 , the mean outdoor temperature was $23.4^{\circ} \mathrm{C}$, and the mean wind speed was $1.9 \mathrm{~m} / \mathrm{s}$ (Table 3 and Figure 3 ).

4.1.1. Surface Temperature of the Plate. The surface temperatures of the plate without PCM was $54.40^{\circ} \mathrm{C}$, that with
Table 3: Average weather data of Test 1.

\begin{tabular}{lccc}
\hline & $\begin{array}{c}\text { Cloud } \\
\text { cover }\end{array}$ & $\begin{array}{c}\text { Air } \\
\text { temperature } \\
\left({ }^{\circ} \mathrm{C}\right)\end{array}$ & $\begin{array}{c}\text { Wind speed } \\
(\mathrm{m} / \mathrm{s})\end{array}$ \\
\hline $9 / 22$ & 0 & 32.5 & 1.3 \\
$9 / 23$ & 9 & 24.6 & 2.2 \\
$9 / 24$ & 3 & 29.8 & 3.1 \\
Average & 4 & 27.2 & 2.2 \\
\hline
\end{tabular}

Bio $26^{\circ} \mathrm{C}$ PCM was $51.75^{\circ} \mathrm{C}$, and that with RT $44^{\circ} \mathrm{C}$ PCM was $47.40^{\circ} \mathrm{C}$. The plate without PCM had the highest surface temperature, followed by Bio $26^{\circ} \mathrm{C}$ PCM and RT $44^{\circ} \mathrm{C} \mathrm{PCM}$, with a difference of up to $7^{\circ} \mathrm{C}$ (Table 4 and Figure 4 ).

4.1.2. Internal Temperature of the Plate. The highest internal temperature of the plate was measured for the plate without PCM $\left(52.75^{\circ} \mathrm{C}\right)$, followed by Bio $26^{\circ} \mathrm{C} \mathrm{PCM}\left(50.00^{\circ} \mathrm{C}\right)$ and RT $44^{\circ} \mathrm{C}$ PCM $\left(42.90^{\circ} \mathrm{C}\right)$. Bio $26^{\circ} \mathrm{C}$ PCM maintained its temperature for about two and a half hours, while RT $44^{\circ} \mathrm{C}$ PCM maintained it for about six hours due to the time lag resulting from the PCM content (Table 5 and Figure 5).

4.1.3. Lower-Side Temperature of the Plate. The lower-side temperatures in the plate showed the same trend as the 


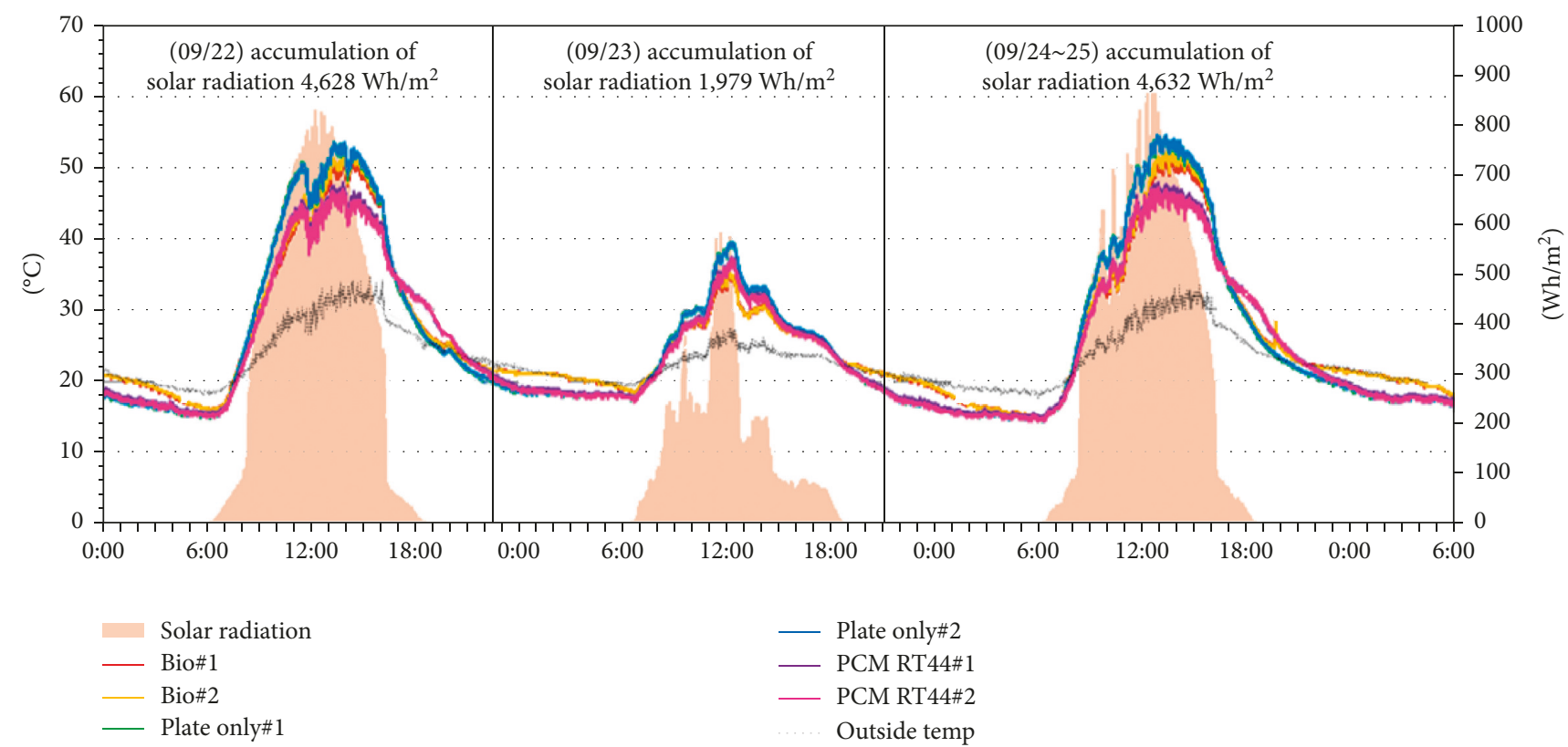

Figure 3: Ambient conditions of Test 1.

TABle 4: Plate surface temperature measurements of Test $1\left({ }^{\circ} \mathrm{C}\right)$.

\begin{tabular}{lccc}
\hline & & Plate surface temperature & \\
& Bio $26^{\circ} \mathrm{C}$ & Single plate & $\mathrm{RT} 44^{\circ} \mathrm{C}$ \\
\hline Maximum & 51.75 & 54.40 & 47.40 \\
Minimum & 14.75 & 14.45 & 14.50 \\
Average & 33.25 & 34.42 & 30.95 \\
\hline
\end{tabular}

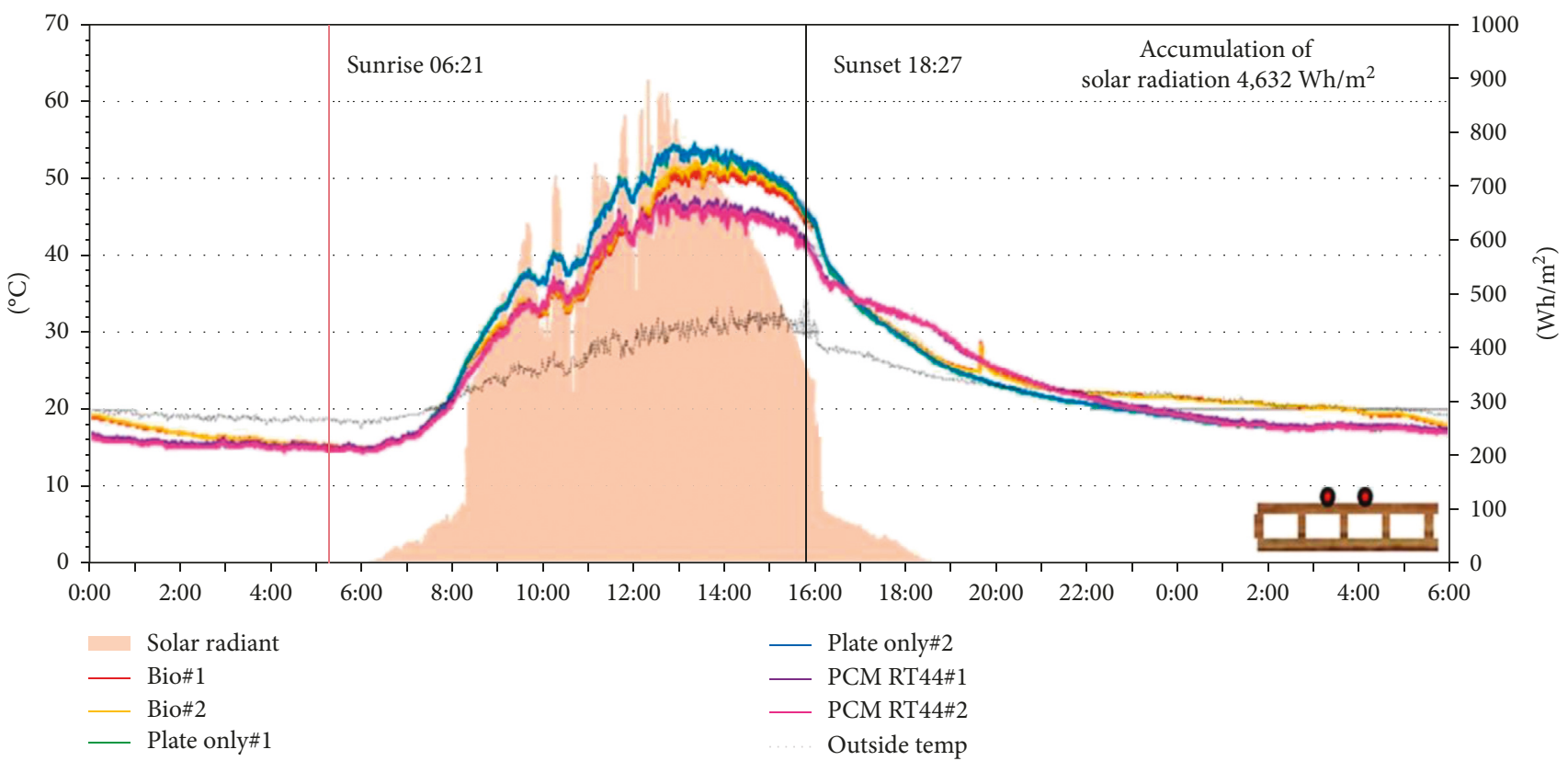

Figure 4: Plate surface temperature graph of Test 1. 
TABle 5: Plate inner temperature measurements of Test $1\left({ }^{\circ} \mathrm{C}\right)$.

\begin{tabular}{lccr}
\hline & & Plate inner temperature & \\
& Bio $26^{\circ} \mathrm{C}$ & Single plate & RT $44^{\circ} \mathrm{C}$ \\
\hline Maximum & 50.00 & 52.75 & 42.90 \\
Minimum & 15.55 & 15.00 & 14.75 \\
Average & 32.78 & 33.88 & 28.83 \\
\hline
\end{tabular}

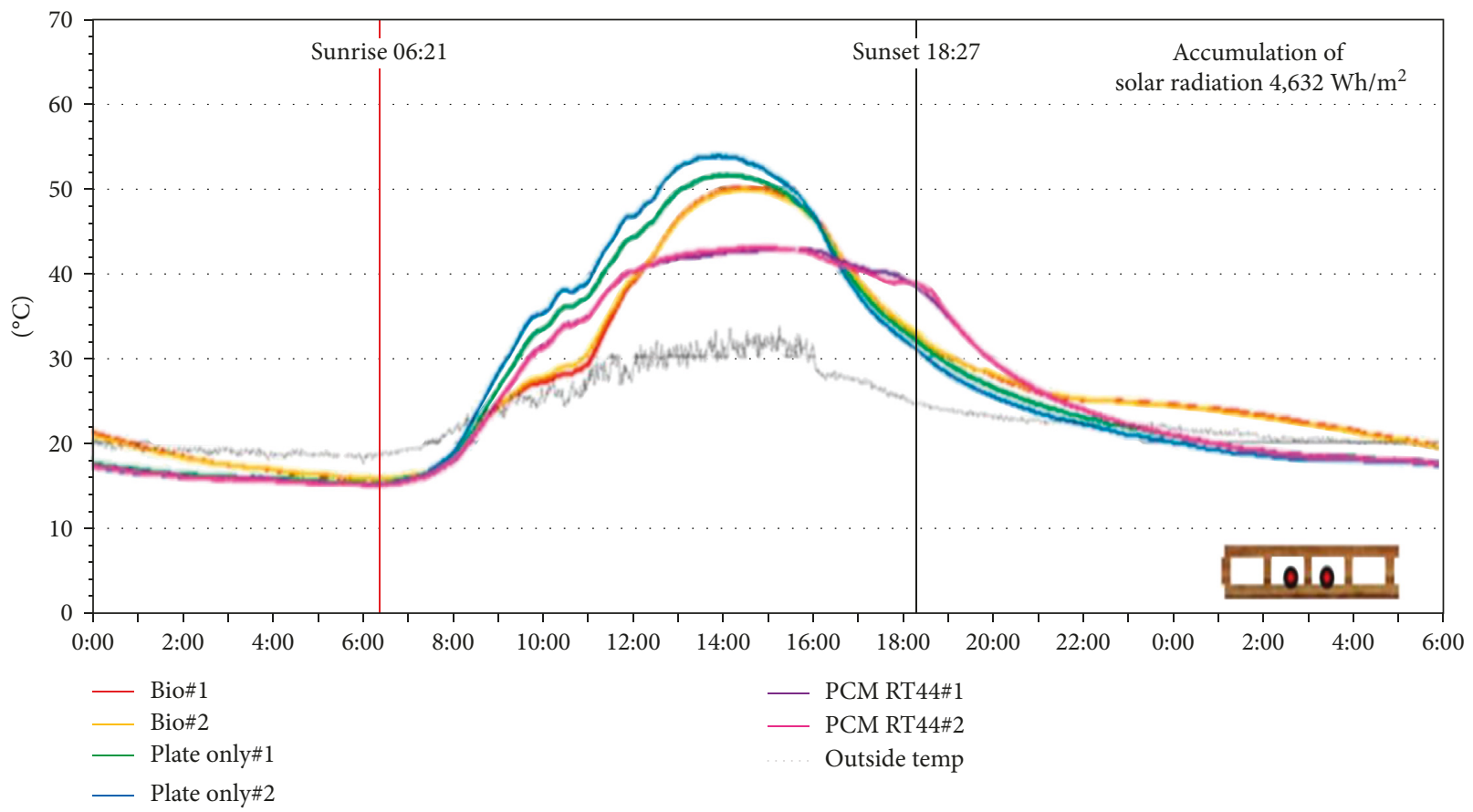

Figure 5: Plate inner temperature graph of Test 1.

surface and internal temperatures. The temperature was lower in the morning and $1-2^{\circ} \mathrm{C}$ higher at night than the internal temperature of the plate (Table 6 and Figure 6).

4.1.4. Indoor Ceiling Temperature. The indoor ceiling temperatures were $38.00^{\circ} \mathrm{C}$ for Bio $26^{\circ} \mathrm{C} \mathrm{PCM}, 36.50^{\circ} \mathrm{C}$ for $\mathrm{RT} 44^{\circ} \mathrm{C} \mathrm{PCM}$, and $39.10^{\circ} \mathrm{C}$ for the plate without PCM. The time when the maximum temperature of the indoor ceiling surface occurred showed that the plate without PCM was 16: 40 , Bio $26^{\circ} \mathrm{C}$ PCM was 17:20, and RT $44^{\circ} \mathrm{C}$ PCM was 17:31. That is, a time lag phenomenon occurred in the case of the Bio $26^{\circ} \mathrm{C}$ and RT $44^{\circ} \mathrm{C}$ PCMs during cooling after sunset compared to the other specimens (Table 7 and Figure 7).

4.1.5. Summary. The test results of Test 1 can be summarized as follows:

(i) The PCM plates had lower surface temperatures than the plate without the PCM.

(ii) The RT $44^{\circ} \mathrm{C}$ PCM exhibited a lower surface temperature than the Bio $26^{\circ} \mathrm{C}$ PCM. This was due to heat loss on the surface as a result of heat acquisition by the internal PCM. This result indicated that RT
TABle 6: Plate bottom temperature measurements of Test $1\left({ }^{\circ} \mathrm{C}\right)$.

\begin{tabular}{lccc}
\hline & \multicolumn{3}{c}{ Plate bottom temperature } \\
& Bio $26^{\circ} \mathrm{C}$ & Single plate & RT $44^{\circ} \mathrm{C}$ \\
\hline Maximum & 45.45 & 48.15 & 41.45 \\
Minimum & 16.55 & 15.65 & 15.35 \\
Average & 31.00 & 31.90 & 28.40 \\
\hline
\end{tabular}

$44^{\circ} \mathrm{C}$ PCM, which has a relatively high phase-change temperature, maintained the maximum point in the range of the phase-change temperature for a longer time.

(iii) Thus, when a mixed material of WPC and PCM was applied to roof finishes, there was a lower surface temperature and time-lag phenomenon than in general building materials.

(iv) RT $44^{\circ} \mathrm{C}$ PCM, which has a melting point of $44^{\circ} \mathrm{C}$, was better at lowering the temperature than Bio $26^{\circ} \mathrm{C}$ PCM.

4.2. Test by Finish Color: Brown and White (Test 2). In Test 2, the packing-type PCMs (Bio $26^{\circ} \mathrm{C} / \mathrm{RT} 44^{\circ} \mathrm{C}$ ) were filled 


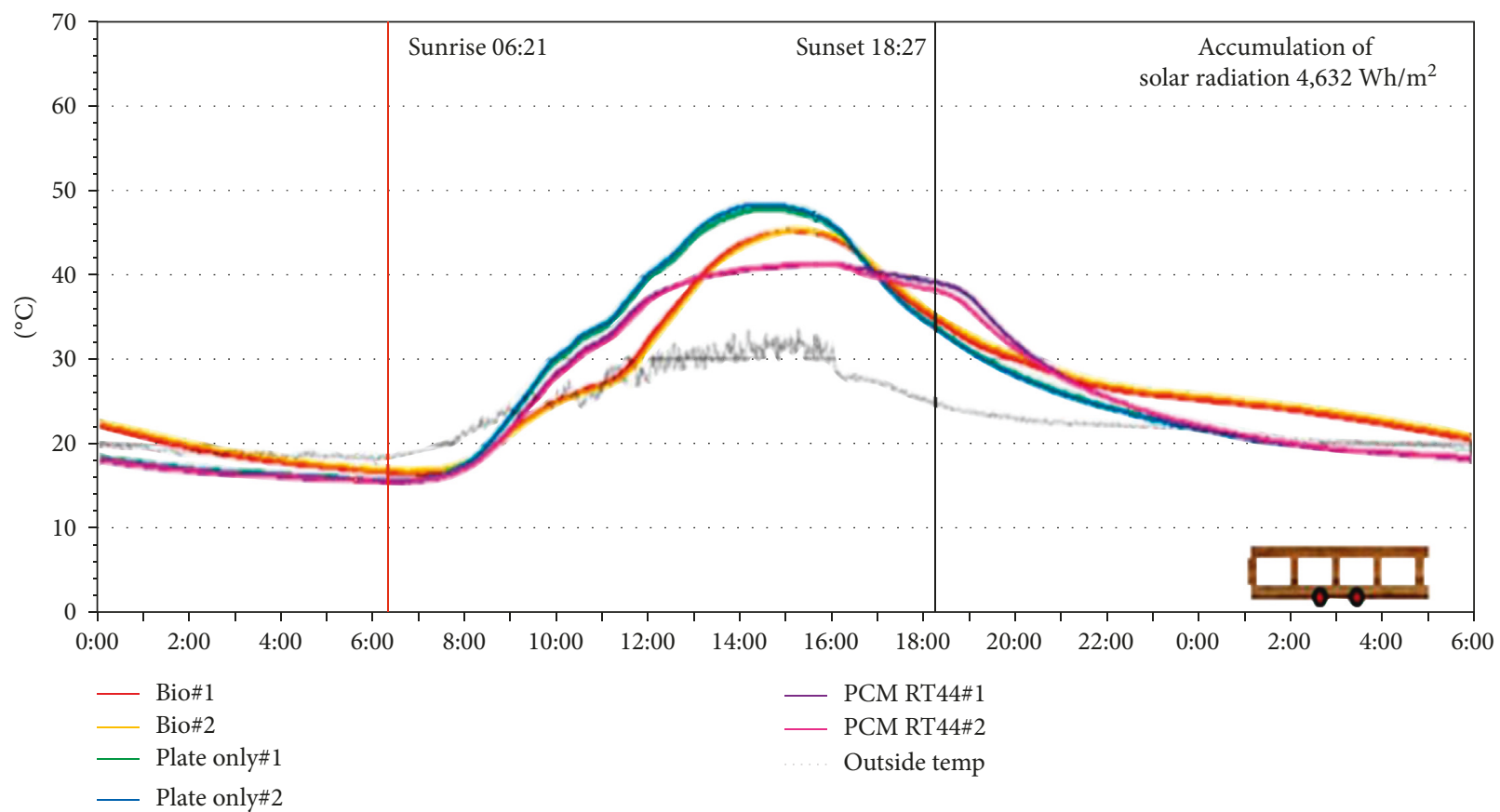

Figure 6: Plate bottom temperature graph of Test 1.

TABLe 7: Ceiling temperature measurement results of Test $1\left({ }^{\circ} \mathrm{C}\right)$.

\begin{tabular}{|c|c|c|c|}
\hline & \multicolumn{3}{|c|}{ Ceiling temperature } \\
\hline & Bio $26^{\circ} \mathrm{C}$ & Single plate & RT $44^{\circ} \mathrm{C}$ \\
\hline Maximum & 38.00 & 39.10 & 36.50 \\
\hline Minimum & 18.90 & 17.70 & 17.90 \\
\hline Average & 28.45 & 28.40 & 27.20 \\
\hline
\end{tabular}

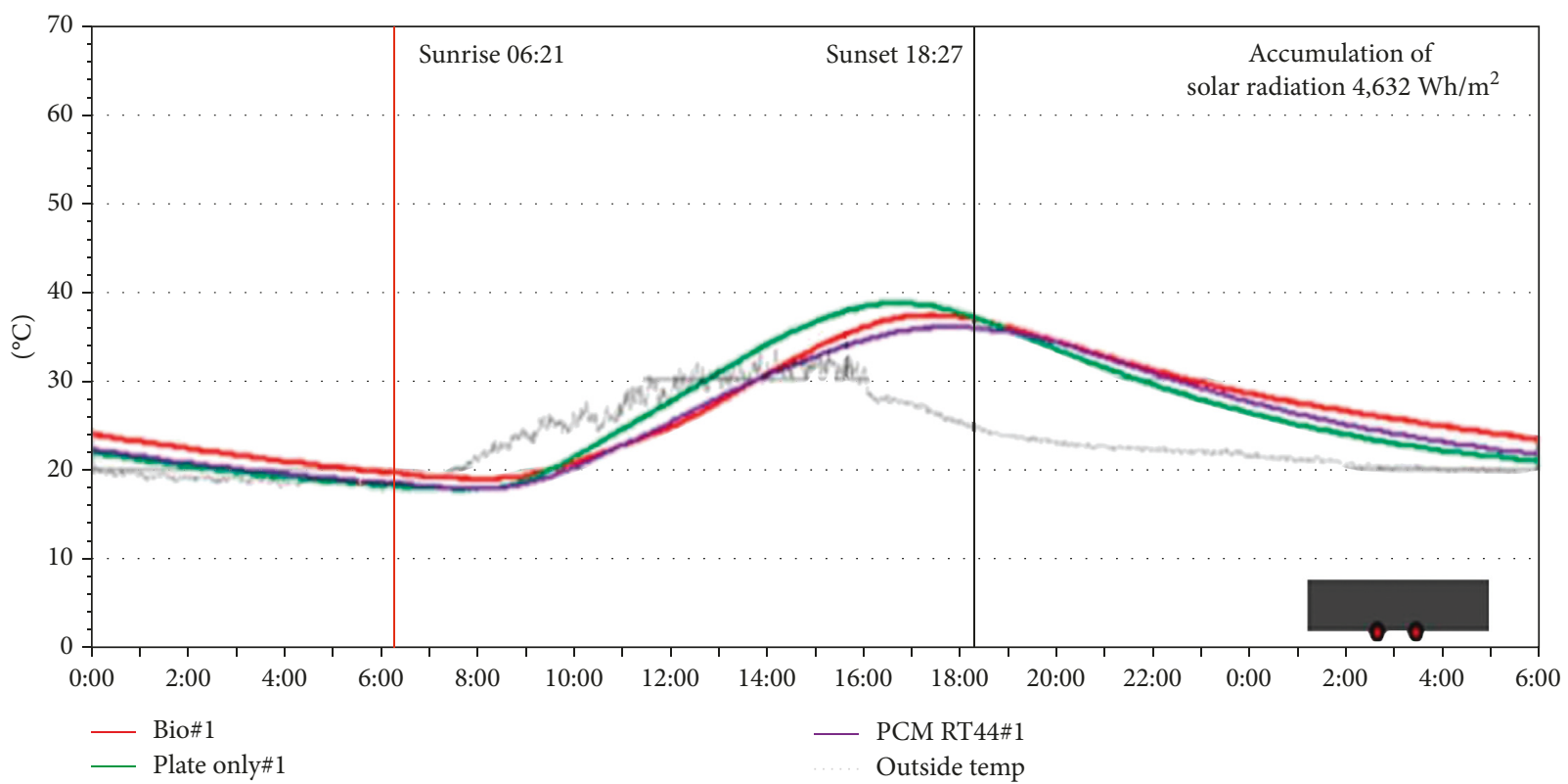

Figure 7: Ceiling temperature graph of Test 1. 
TABle 8: Test 2 summary.

\begin{tabular}{llccc}
\hline & & RT 44 PCM & & Bio 26 PCM \\
& & Color & Color \\
\hline Experimental group & White & & Brown & White \\
\hline
\end{tabular}

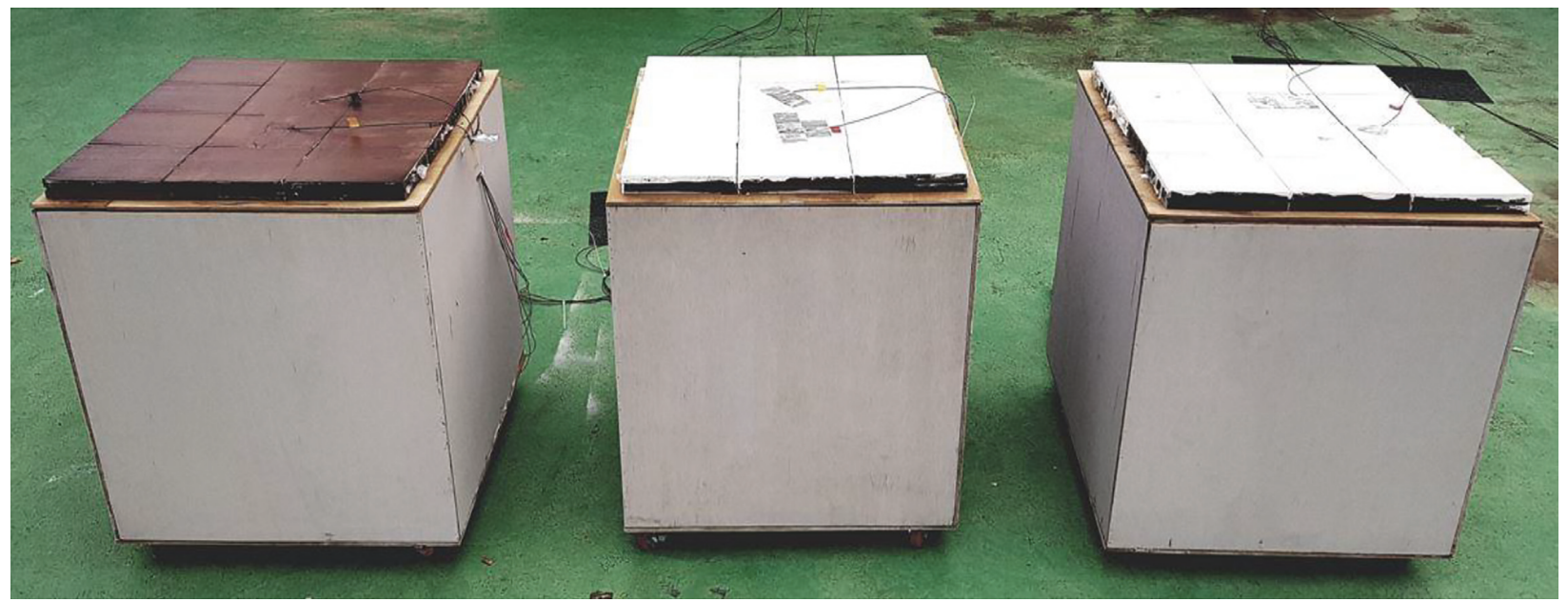

FIgURE 8: Scale-model experiment finish colors (Test 2).

Table 9: Average weather data of Test 2.

\begin{tabular}{lccc}
\hline & Cloud amount & Air temperature $\left({ }^{\circ} \mathrm{C}\right)$ & Wind speed $(\mathrm{m} / \mathrm{s})$ \\
\hline $10 / 20$ & 0 & 24.8 & 1.8 \\
$10 / 21$ & 0 & 22.7 & 3.5 \\
$10 / 22$ & 5 & 22.9 & 1.8 \\
$10 / 23$ & 6 & 21.1 & 4.2 \\
$10 / 24$ & 0 & 21.0 & 3.6 \\
\hline
\end{tabular}

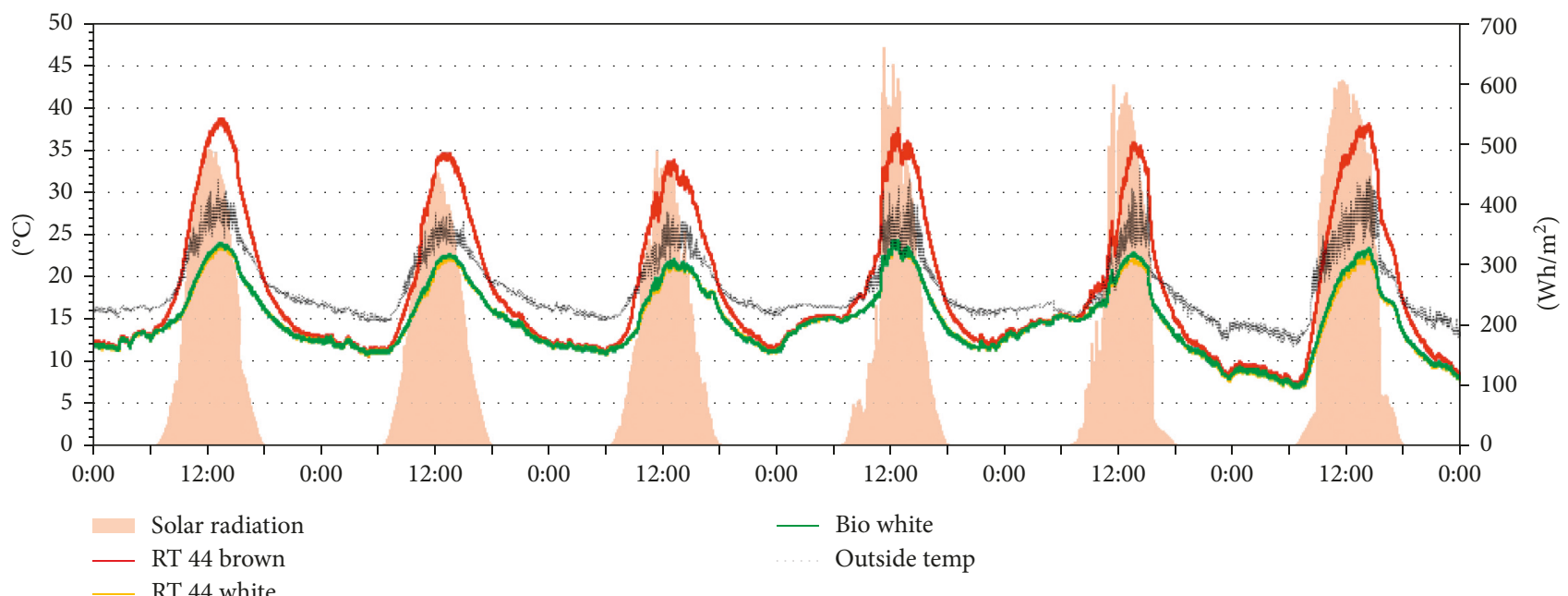

FIgUre 9: Ambient conditions of Test 2.

into the WPC and applied to a rooftop. The performance of PCM was measured for different surface finish colors (brown and white). Brown was selected because it is generally used in existing WPC products, and white was selected because the finish color of the cool roof is white (Table 8 and Figure 8). 
Table 10: Plate surface temperature measurements of Test $2\left({ }^{\circ} \mathrm{C}\right)$.

\begin{tabular}{lccc}
\hline & & Plate surface temperature & \\
& $\mathrm{RT} 44^{\circ} \mathrm{C}$ brown & RT $44^{\circ} \mathrm{C}$ white & Bio $26^{\circ} \mathrm{C}$ white \\
\hline Maximum & 38.85 & 23.70 & 24.00 \\
Minimum & 11.35 & 11.25 & 11.25 \\
Average & 25.10 & 17.48 & 17.63 \\
\hline
\end{tabular}

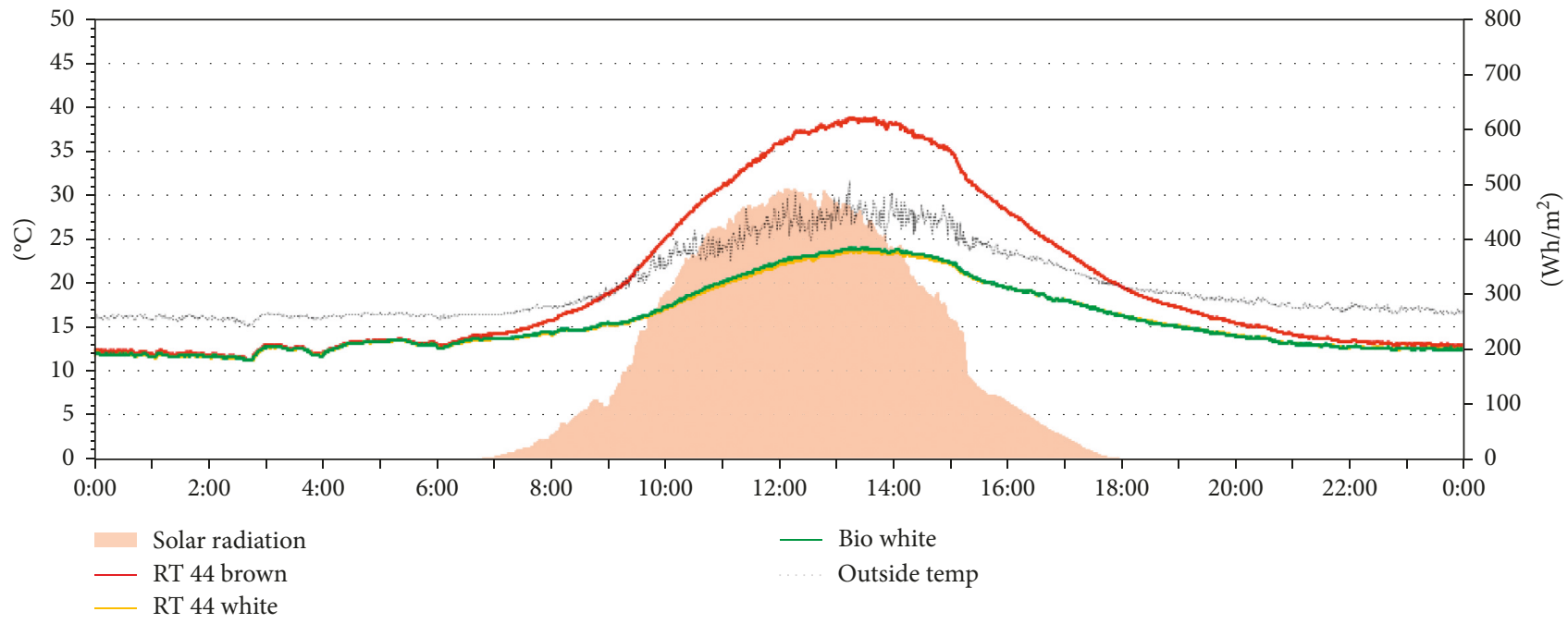

Figure 10: Plate surface temperature graph of Test 2.

Table 11: Plate inner temperature measurements of Test $2\left({ }^{\circ} \mathrm{C}\right)$.

\begin{tabular}{lccr}
\hline & & Plate inner temperature & \\
& RT $44^{\circ} \mathrm{C}$ brown & RT $44^{\circ} \mathrm{C}$ white & Bio $26^{\circ} \mathrm{C}$ white \\
\hline Maximum & 38.15 & 22.80 & 27.00 \\
Minimum & 13.05 & 12.65 & 17.65 \\
Average & 25.60 & 17.73 & 22.33 \\
\hline
\end{tabular}

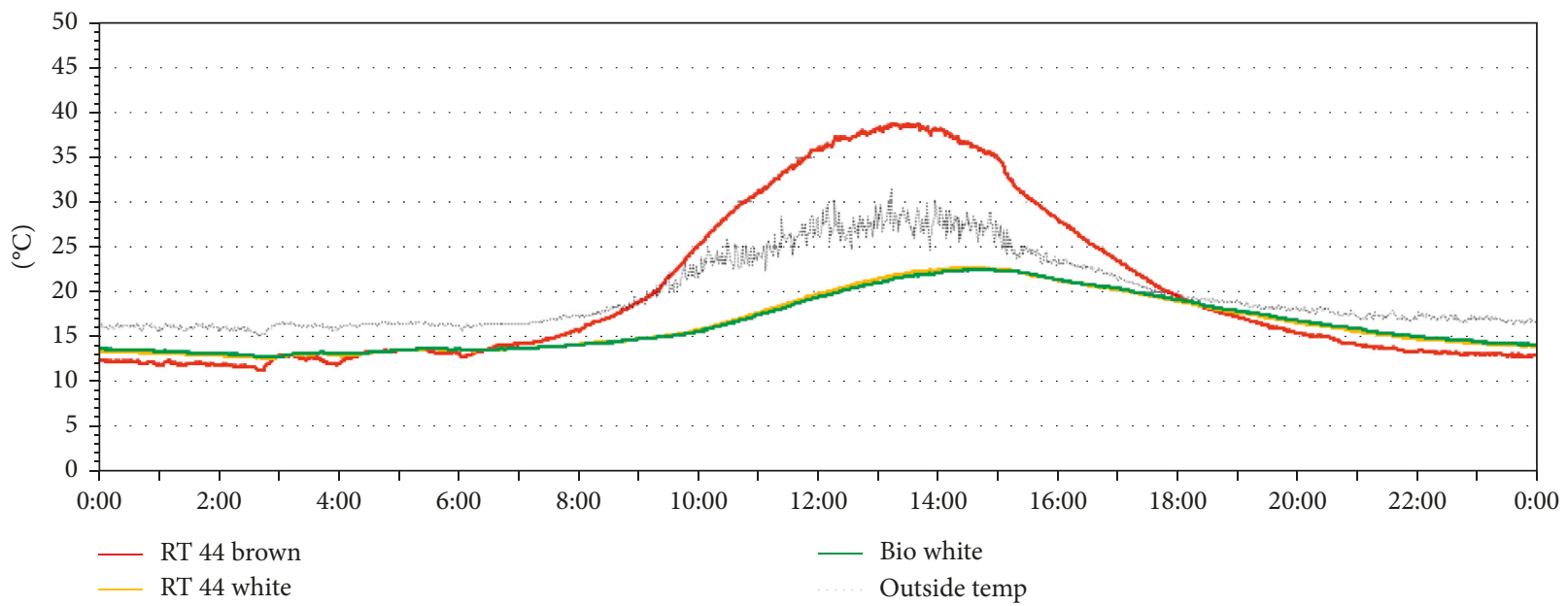

Figure 11: Plate inner temperature graph of Test 2. 
TABle 12: Plate bottom temperature measurements of Test $2\left({ }^{\circ} \mathrm{C}\right)$.

\begin{tabular}{lccc}
\hline & & Plate bottom temperature & \\
& $\mathrm{RT} 44^{\circ} \mathrm{C}$ brown & RT $44^{\circ} \mathrm{C}$ white & Bio $26^{\circ} \mathrm{C}$ white \\
\hline Maximum & 36.10 & 22.60 & 22.40 \\
Minimum & 13.80 & 13.25 & 13.75 \\
Average & 24.95 & 17.93 & 18.08 \\
\hline
\end{tabular}

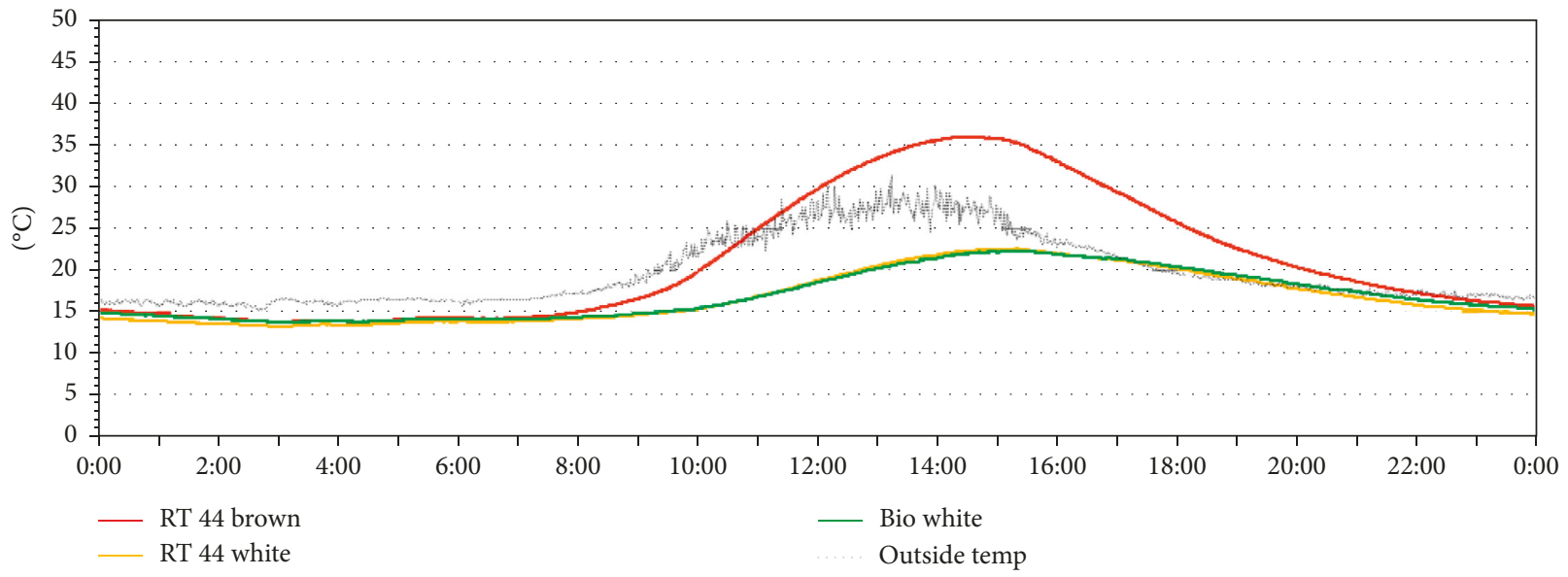

Figure 12: Plate bottom temperature graph of Test 2.

TABle 13: Ceiling temperature measurements of Test $2\left({ }^{\circ} \mathrm{C}\right)$.

\begin{tabular}{lccr}
\hline & & Ceiling temperature \\
& $\mathrm{RT} 44^{\circ} \mathrm{C}$ brown & RT $44^{\circ} \mathrm{C}$ white & Bio $26^{\circ} \mathrm{C}$ white \\
\hline Maximum & 29.40 & 24.00 & 24.40 \\
Minimum & 16.00 & 15.20 & 15.90 \\
Average & 22.70 & 19.60 & 20.15 \\
\hline
\end{tabular}

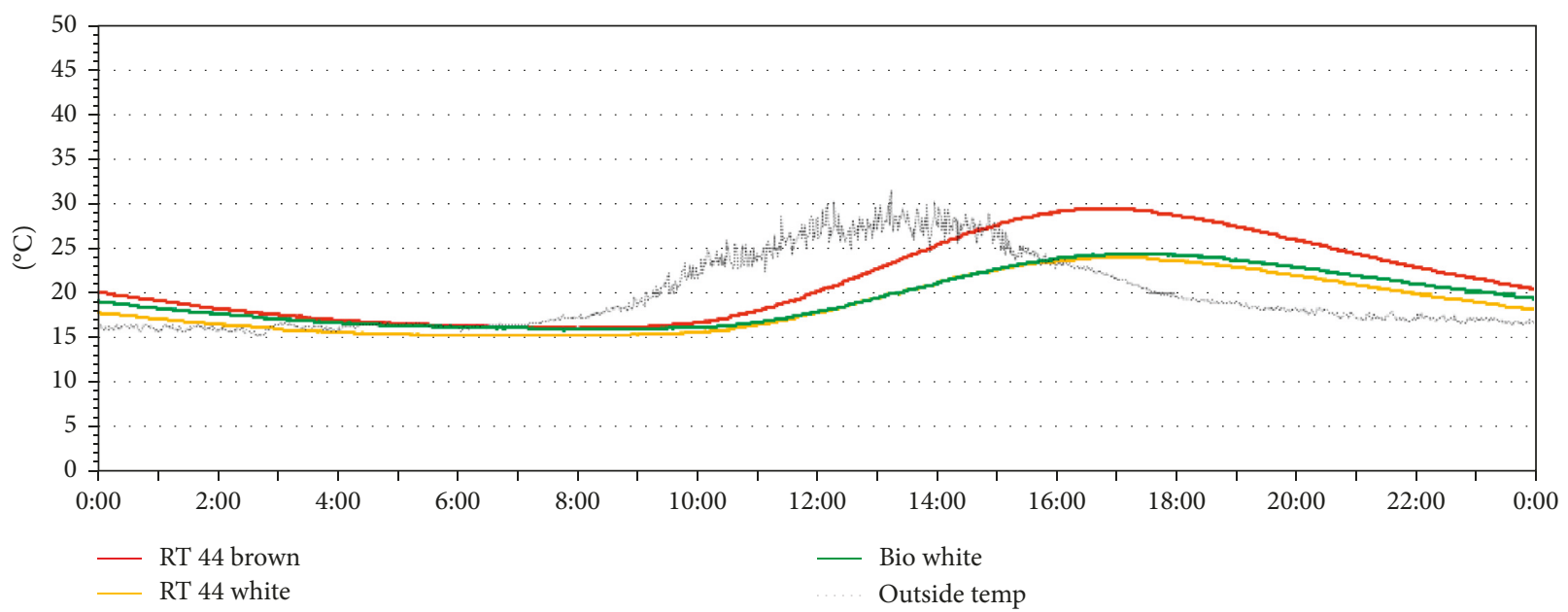

Figure 13: Ceiling temperature graph of Test 2. 
The test was conducted on the rooftop of a building at Chung-Ang University in Heukseok-dong, Dongjak-gu, Seoul, from October 20 to 25, 2015. The weather conditions had no interference from solar radiation. The mean cloud cover was 2.3 , the mean outdoor temperature was $16.6^{\circ} \mathrm{C}$, and the mean wind speed was $1.6 \mathrm{~m} / \mathrm{s}$ (Table 9 and Figure 9).

4.2.1. Surface Temperature of the Plate. The highest surface temperature for the brown model was $38.85^{\circ} \mathrm{C}$ and that of the white model was $23.70^{\circ} \mathrm{C}$, resulting in a temperature difference of approximately $15.15^{\circ} \mathrm{C}$. No significant difference in surface temperature was revealed between $\mathrm{RT} 44^{\circ} \mathrm{C}$ and Bio $26^{\circ} \mathrm{C}$ PCMs for white models (Table 10 and Figure 10).

4.2.2. Internal Temperature of the Plate. The highest internal plate temperature for the brown finish was $38.15^{\circ} \mathrm{C}$ and that for the white finish was $22.80^{\circ} \mathrm{C}$, resulting in a temperature difference of approximately $15.35^{\circ} \mathrm{C}$. The internal temperature of the white RT $44^{\circ} \mathrm{C}$ model was $4.60^{\circ} \mathrm{C}$ lower than that of the white Bio $26^{\circ} \mathrm{C}$ model on average (Table 11 and Figure 11).

4.2.3. Lower-Side Temperature of the Plate. The highest lower-side temperature of the plate for the brown model was $36.10^{\circ} \mathrm{C}$ and that of the white model was $22.60^{\circ} \mathrm{C}$, resulting in a temperature difference of approximately $13.50^{\circ} \mathrm{C}$. There was no significant difference in the lower side temperature between the RT $44^{\circ} \mathrm{C}$ and Bio $26^{\circ} \mathrm{C}$ PCMs for the white models (Table 12 and Figure 12).

4.2.4. Indoor Ceiling Temperature. The highest indoor ceiling temperature for the brown model was $29.40^{\circ} \mathrm{C}$ and that of the white model was $24.00^{\circ} \mathrm{C}$, resulting in a temperature difference of approximately $5.40^{\circ} \mathrm{C}$. There was no significant difference between RT $44^{\circ} \mathrm{C}$ and Bio $26^{\circ} \mathrm{C}$ PCMs for the white models (Table 13 and Figure 13).

4.2.5. Summary. In Test 2, a packing-type PCM (Bio $26^{\circ} \mathrm{C} / \mathrm{RT} 44^{\circ} \mathrm{C}$ ) was filled into the WPC, and tests were conducted using brown and white of surface finishes. The test results are summarized as follows:

(i) The brown model had a surface temperature of $38.85^{\circ} \mathrm{C}$ and that of the white was $23.70^{\circ} \mathrm{C}$, indicating that the white color resulted in a lower temperature distribution by $15.15^{\circ} \mathrm{C}$.

(ii) The internal temperature of the white model was $16.35^{\circ} \mathrm{C}$ lower than that of the brown model. The lower-side temperature of the plate of the white model was $13.50^{\circ} \mathrm{C}$ lower than that of the brown model. The white model maintained a $5.40^{\circ} \mathrm{C}$ lower ceiling temperature distribution than that of the brown model due to the difference in surface temperature.

(iii) For the white models, the upper side temperature of $\mathrm{RT} 44^{\circ} \mathrm{C}$ was $5.00^{\circ} \mathrm{C}$ lower than that of Bio $26^{\circ} \mathrm{C}$, but there was no significant difference in the ceiling temperature.

\section{Discussion}

In this study, performance tests were conducted in which PCMs were combined with a cool roof to reduce the cooling load in summer and the heating load in winter. In the literature, the volume of the PCM inside the roof finish was large compared to the thickness of the roof. However, this study was unable to measure the thickness of the roof accurately due to the scale-model test. Thus, the amount of PCM could not be calculated precisely compared to the roof thickness, depending on the scale; thermal conductance changes in the linear manner and thermal mass changes in a cubic manner; and the miniature scale-model with specifications is not detailed enough to be applied to real buildings. However, the results of the scale model test clearly verified the thermal storage performance. When the WPC with PCM was fabricated, its thermal conductivity was measured as $0.55 \mathrm{~W} / \mathrm{m} \cdot \mathrm{K}$ on average through a TCi analysis. In the future, products made from stronger materials with lower thermal conductivity will be applied to reduce the surface temperature even further.

\section{Conclusion}

In this study, packing-type PCMs were inserted into WPC, and a scale-model test was conducted using different colors. The results are summarized as follows:

(1) The PCM plates lowered the surface temperature more than the plate without PCM and exhibited a longer time lag. RT $44^{\circ} \mathrm{C}$ PCM was more effective at reducing the surface temperature than Bio $26^{\circ} \mathrm{C}$ PCM.

(2) The white finish resulted in a lower temperature distribution by $13.50^{\circ} \mathrm{C}$ to $16.35^{\circ} \mathrm{C}$ than brown. Furthermore, the white finish maintained a $5.40^{\circ} \mathrm{C}$ lower indoor temperature distribution than brown due to the difference in surface temperature. Thus, the scale-model test of the PCM cool roof demonstrated that cooling and heating loads of buildings could be decreased because the roof surface temperature can be reduced.

\section{Conflicts of Interest}

The authors declare that they have no conflicts of interest.

\section{Acknowledgments}

This research was supported by the Chung-Ang University Research Scholarship Grants in 2017.

\section{References}

[1] R. Levinson and H. Akbari, "Potential benefits of cool roofs on commercial buildings: conserving energy, saving money, and reducing emission of greenhouse gases and air pollutants," Energy Efficiency, vol. 3, no. 1, pp. 53-109, 2010.

[2] A. Jayalath, L. Aye, P. Mendis, and T. Ngo, "Effects of phase change material roof layers on thermal performanceof a residential building in Melbourne and Sydney," Energy and Buildings, vol. 121, pp. 152-158, 2016. 
[3] L. Dong, Z. Yumeng, L. Changyu, and W. Guozhong, "Numerical analysis on thermal performance of roof contained PCM of a single residential building," Energy Conversion and Management, vol. 100, pp. 147-156, 2015.

[4] M. A. Izquierdo-Barrientos, J. F. Belmonte, D. RodriguezSanchez, A. E. Molina, and J. A. Almendros-Ibanez, "A numerical study of external building walls containing phase change materials (PCM)," Applied Thermal Engineering, vol. 47, pp. 73-85, 2012.

[5] H. Akeiber, P. Nejat, M. Z. A. Majid et al., "A review on phase change material (PCM) for sustainable passive cooling in building envelopes," Renewable and Sustainable Energy Reviews, vol. 60, pp. 1470-1497, 2016.

[6] X. Jin, S. Zhang, X. Xu, and X. Zhang, "Effects of PCM state on its phase change performance and the thermal performance of building walls," Building and Environment, vol. 81, pp. 334339, 2014.

[7] S. Harikrishnan, M. Deenadhayalan, and S. Kalaiselvam, "Experimental investigation of solidification and melting characteristics of composite PCMs for building heating application," Energy Conversion and Management, vol. 86, pp. 864-872, 2014.

[8] M. Saffari, A. de Gracia, S. Ushak, and L. F. Cabeza, "Passive cooling of buildings with phase change materials using wholebuilding energy simulation tools: a review," Renewable and Sustainable Energy Reviews, vol. 80, pp. 1239-1255, 2017.

[9] E. Meng, H. Yu, and B. Zhou, "Study of the thermal behavior of the composite phase change material (PCM) room in summer and winter," Applied Thermal Engineering, vol. 126, pp. 212-225, 2017.

[10] Y. K. Yang, I. S. Kang, M. H. Chung, J. C. Park, and S. M. Kim, "Effect of PCM cool roof system on the reduction in urban heat island phenomenon," Building and Environment, vol. 112, pp. 411-421, 2017.

[11] J. Huang, J. Hanford, and F. Yang, Residential Heating and Cooling Loads Component Analysis, Environmental Energy Technologies Division, Building Technologies Department, Lawrence Berkeley National Laboratory, University of California, Oakland, CA, USA, 1999.

[12] H. M. Chou, C. R. Chen, and V. L. Nguyen, "A new design of metal-sheet cool roof using PCM," Energy and Buildings, vol. 57, pp. 42-50, 2013.

[13] T. Karlessi, M. Santamouris, A. Synnefa, D. Assimakopoulos, P. Didaskalopoulos, and K. Apostolakis, "Development and testing of PCM doped cool colored coatings to mitigate urban heat island and cool buildings," Building and Environment, vol. 46, no. 3, pp. 570-576, 2011.

[14] A. Pasupathy and R. Velraj, "Effect of double layer phase change material in building roof for year round thermal management," Energy and Buildings, vol. 40, no. 3, pp. 193203, 2008.

[15] K. K. Roman, T. O’Brien, J. B. Alvey, and O. Woo, "Simulating the effects of cool roof and PCM (phase change materials) based roof to mitigate UHI (urban heat island) in prominent US cities," Energy, vol. 96, pp. 103-117, 2016.

[16] S. Lu, Y. Chen, S. Liu, and X. Kong, "Experimental research on a novel energy efficiency roof coupled with PCM and cool materials," Energy and Buildings, vol. 127, pp. 159-169, 2016.

[17] M. H. Chung, "Development of PCM cool system to control urban heat island considering temperate climatic conditions," Energy and Buildings, vol. 116, pp. 341-348, 2016.

[18] Phase Change Energy Solutions, http://www.phasechange. com/, 2017. 


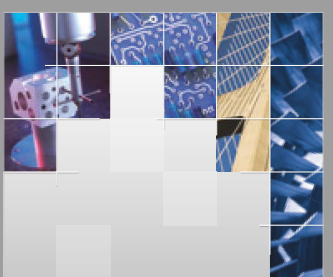

\section{Enfincering}
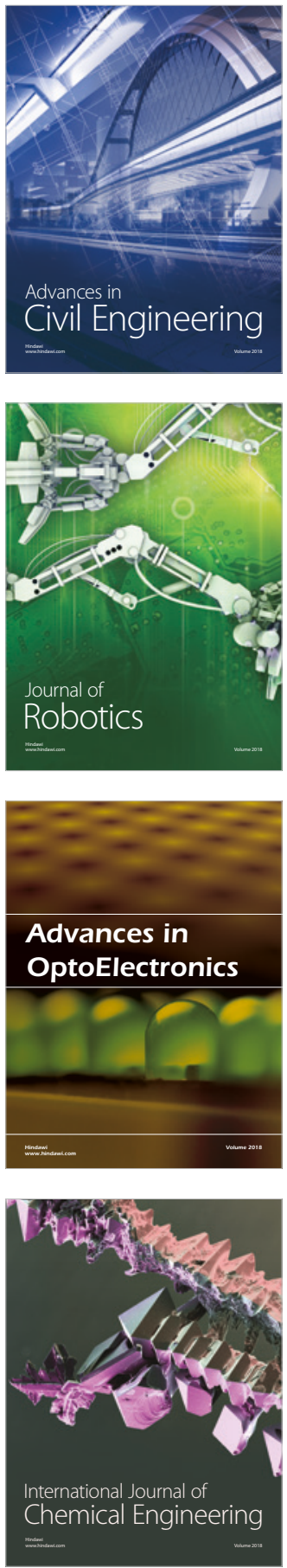

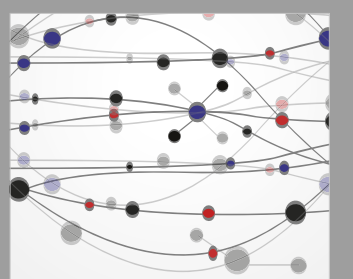

\section{Rotating \\ Machinery}

The Scientific World Journal

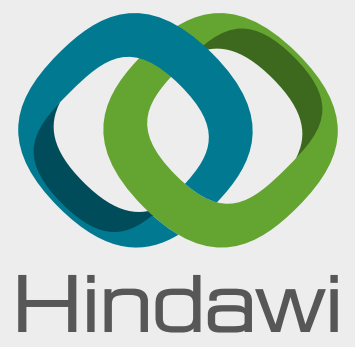

Submit your manuscripts at

www.hindawi.com
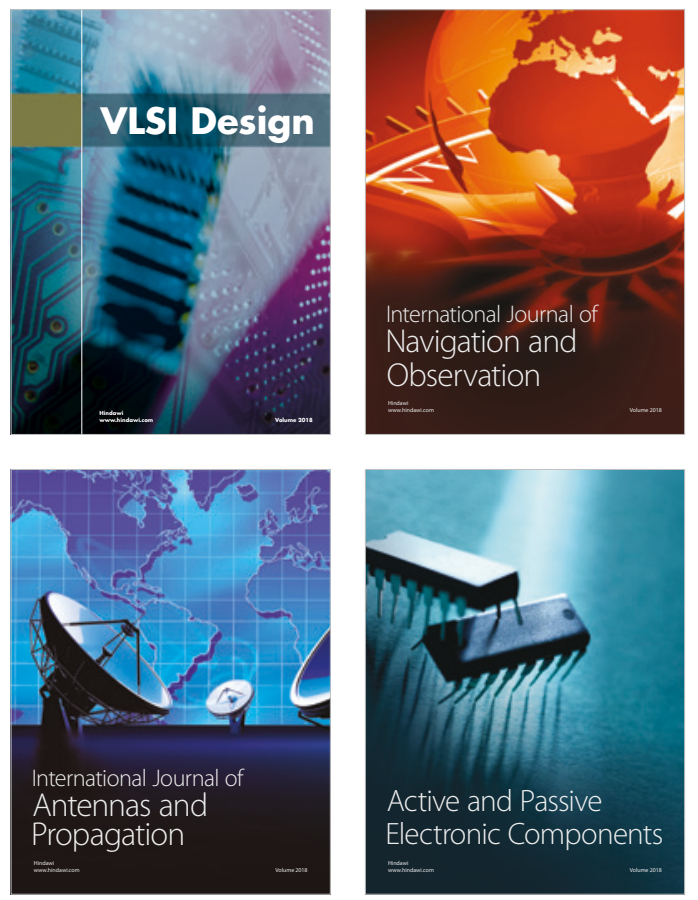
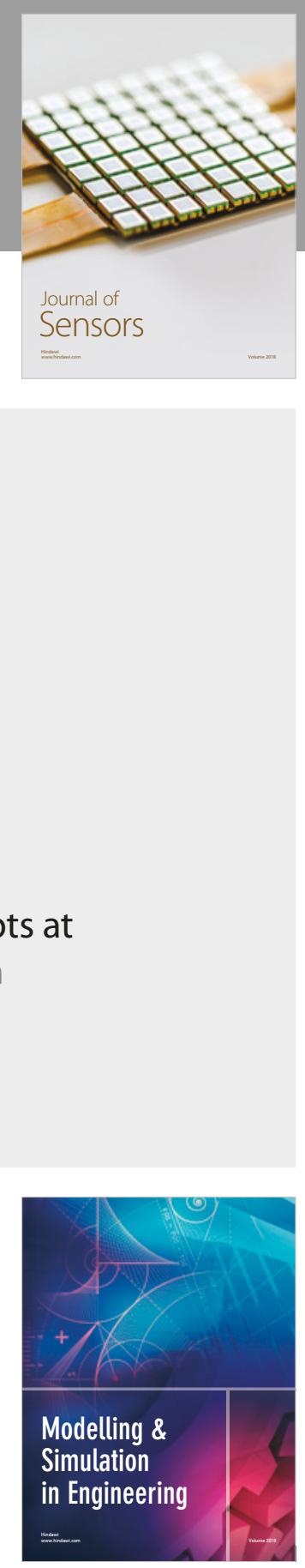

\section{Advances \\ Multimedia}
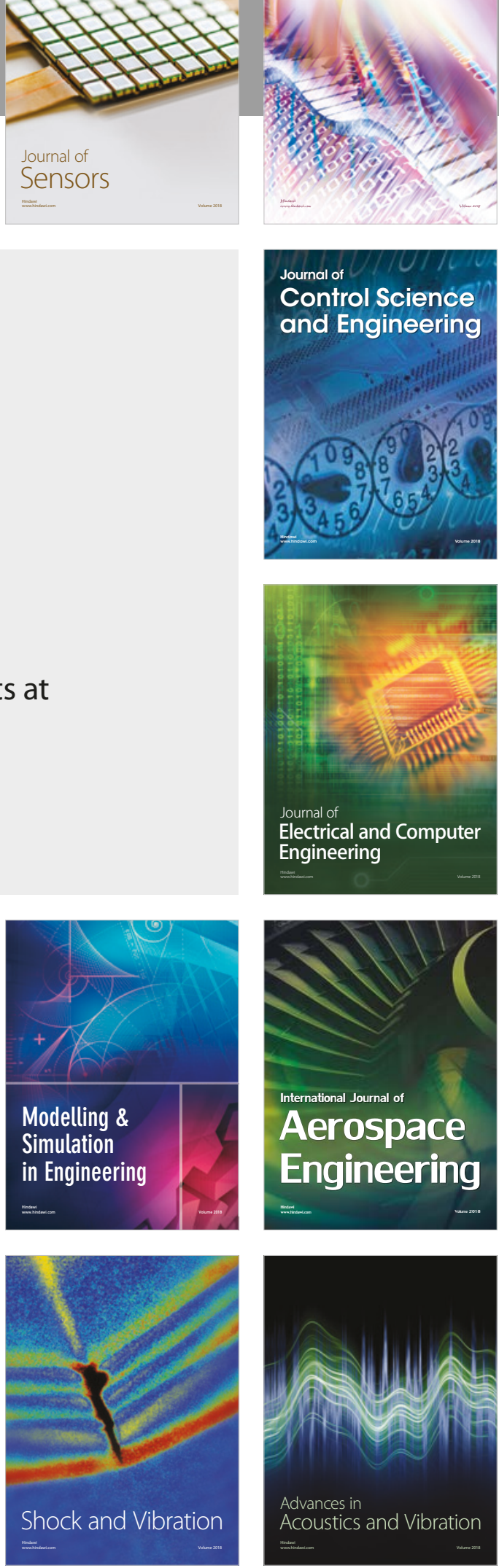